Polgári Szemle, 15. évf. 1-3. szám, 2019, 399-405., DOI: 10.24307/psz.2019.0925

Botos Balázs

\title{
A ciprusi gazdaság sokarcúsága
}

\section{The Multiplicity of the Cypriot Economy}

\section{ÖSSZEFOGLALÁS}

A cikk áttekinti az elmúlt évek gazdaságpolitikai lépéseit, amelyek meghatározzák Ciprus jelenlegi gazdasági helyzetét. A csôd elôl meneküló ország hat éve kötött megállapodást az EU-val és az IMF-fel, de ennek következményei máig társadalmi feszültségeket szítanak. Az aktuális gazdasági helyzetkép egyébként ellentmondásos, mivel a javuló költségvetési adatok mellett máig igen magas a bankokban a rossz hitelek aránya, és kevés változás látszik a reálgazdaságot illetôen is. A 2011ben felfedezett offshore gázvagyonhoz fúzôdố remények ugyan továbbélnek, de a realizálás igen lassan halad elôre, ráadásul a sziget megosztottságának ténye ezen a területen is konfliktusokat szül.

Journal of Economic Literature (JEL) kódok: E52, G33, H6, L95

Kulcsszavak: Ciprus, haircut, gazdaságpolitika, versenyképesség, földgázvagyon, hitelállomány

\section{SUMMARY}

The article reviews the economy policy of the past few years, which determines the current state of the economy in Cyprus. In order to avoid bankruptcy, six years ago the country signed an agreement with the EU and the IMF, but the consequences have still been causing social tensions to this very date. The current situation is contradictory: improving budget data is accompanied by a high number of non-performing loans in banks, and there is little change in the real economy. Although the hopes related to offshore gas assets, discovered in 2011, still survive, realization is very slow, and the division of the island gives rise to conflicts in this area, too.

Journal of Economic Literature (JEL) codes: E52, G33, H6, L95

Keywords: Cyprus, haircut, economy policy, competitiveness, gas assets, loans

Dr. Botos BALÁzs, volt ciprusi nagykövet (botos530@gmail.com). 


\section{Tudományos múhely}

Ciprus sokarcúságáról az idegenforgalmi kiadványok - tegyük hozzá, jogosan ódákat zengenek. Az ország gazdasági és politikai helyzetének megítélése már korántsem ilyen egyértelmú. Pontosabban, a politikai helyzet jellemzése látszólag kevésbé bonyolult, hiszen az országon belül stabilitás van, ugyanakkor a legfájóbb területen, a szigetország újraegyesítésének kérdésében évtizedek óta nincs elôrehaladás. A gazdasági helyzet összetettebb, és a hat ével ezelôtti mélypont után most pozitív és negatív jeleket egyaránt fel lehet fedezni. A következókben áttekintjük a közelmúlt és a jelen azon gazdaságpolitikai történéseit, amelyek segíthetik a szigetország jelenlegi gazdasági helyzetét illetố tisztánlátást, röviden utalva csak a szükséges politikai tényezókre.

\section{TÖRTÉNT HAT ÉVE?}

Az Európai Bizottság 2012. májusi országjelentése Ciprus „igen súlyos” gazdasági egyensúlytalanságait emelte ki, és további intézkedéseket sürgetett a túlzott deficit csökkentése érdekében. A gondok hátterében banki oldalról a nem prudens hitelkihelyezések, a rossz hitelek óriási volumene álltak, nem utolsósorban a ciprusi bankok masszív részvétele a görög adósságleírásban, költségvetési oldalról pedig a magas adósságszint fenyegette leginkább a gazdasági egyensúlyt. Egy 2012. évi cikkben kifejtett véleményem szerint egyre valószínúbbnek tûnt, hogy Ciprusnak is igénybe kell vennie az EU mentốcsomagját (Botos, 2012).

A jóslat bevált, az erról folyó tárgyalások 2012 második felében megkezdôdtek. A kérelem benyújtása és a megállapodás aláírása között kilenc hónap telt el, és eközben a helyzet egyre romlott. Végül is Ciprus kapott 10 milliárd eurót (a kért 17 milliárd euró helyett), és a különbözetet - minden korábbi segélycsomagtól eltérôen - a szigetországnak saját magának kellett kitermelni. De milyen forrásokból, és milyen következményekkel? 2013. március 25-én az azóta már megszúnt Laiki Bank betétesei arra ébredtek, hogy 100 ezer euró feletti megtakarításaik az elózô éjszaka alatt az utolsó centig elvesztek. Hat ével késôbb, 2019-ben az áldozatok még mindig azt remélik, hogy bírósági vagy kormányzati döntések alapján visszakapják a pénzüket vagy legalábbis annak egy részét.

2013 márciusában a ciprusi kormány és az Eurogroup közötti hosszadalmas és szövevényes tárgyalások következményeként a Laiki Bankban levô betétek 100 ezer eurón felüli része teljesen elveszett, míg a Bank of Cyprusban a 100 ezer euró feletti betétek 47,5 százaléka jutott erre a sorsra. Mindez része volt annak a megállapodásnak, az ún. „bailout” szerzôdésnek, amelyet a csốd elôl menekülő ország kénytelen volt az EU és az IMF nyomására elfogadni. A ciprusi Pénzügyminisztérium legutóbbi adatai szerint az elveszett betétek összege 7,7 milliárd eurót tett ki, míg a banki részvényekké konvertált értékpapírok nominális értéke 1,2 milliárd euró volt.

A veszteséget szenvedett betétesek a kezdeti - és eredménytelen - tüntetések után elkezdték keresni annak a lehetôségét, hogy jogi úton lépjenek fel pénzük visszaszerzése és a felelôsök számonkérése érdekében. Miután a ciprusi Legfelsóbb Bíróság 2013 nyarán mintegy 3000 beadványt utasított el a témában, a betétesek megalakították a Laiki Betéteseinek Szövetségét (rövidített neve: SYKALA), 


\section{Tudományos múhely}

amelynek ma 4500 regisztrált tagja van. A SYKALA deklarált célja: segíteni a szerintük jogtalan akció révén a tagoktól ellopott pénz visszaigénylését és a felelôsök számonkérését. Mintegy 10 ezer károsult kért eddig segítséget vagy tanácsot a szövetségtôl, amelynek rendezvényein tömegek vesznek részt.

A SYKALA egyszerre indított eljárásokat Cipruson és nemzetközi fórumokon is, beleértve az Európai Bíróságot is. A tömeges polgári peres eljárás a ciprusi kormány, a központi bank és a Laiki Bank menedzsmentje ellen irányul. A központi bank ellen az a vád, hogy még a "haircut” elôtti napokban is azt deklarálta, hogy a ciprusi bankrendszer stabil és megbízható, a köztársasági elnök pedig határozottan kijelentette, hogy Ciprus soha nem fog semmiféle „haircut” megállapodást elfogadni. Természetesen a "haircut” nemcsak a magánbetéteseket érintette, hanem a vállalkozásokat is. Ráadásul a vállalkozók nemcsak saját pénzüket vesztették el, hanem például a megrendelóik által befizetett elólegeket vagy az adófizetésre tartalékolt összegeket is.

A SYKALA régóta sürgette a kormányt és a pénzügyminisztert, hogy terjesszék a parlament elé egy ún. Szolidaritási Alap létrehozását, amely legalább részlegesen tudná kompenzálni a károsultakat. Felhívják a figyelmet arra is, hogy azok, akik az adófizetôk pénzét féltik a Szolidaritási Alaptól, gondoljanak arra, hogy az „ellopott” pénzek mentették meg Ciprust a teljes pénzügyi csôdtôl, és e nélkül ma nem léteznének sem adófizetôk (csak „éhezố állampolgárok”), sem múködô állam.

A kormány egyébként már 2017 novemberében döntött arról, hogy 25 millió euróval létrehozza a Szolidaritási Ala- pot, de az ellenzéki pártok elutasították a tervet arra való hivatkozással, hogy az akció csak Nikosz Anasztasziadesz elnök újraválasztását kívánja segíteni. A közelmúltban Harisz Georgiadesz ciprusi pénzügyminiszter ismételten kijelentette, hogy az alapot létrehozzák, de véleménye szerint arról, hogy ki, milyen arányban részesedjen a kompenzációból, csak akkor érdemes határozni, ha az Alap tartalékai elérik a 300 millió eurót. Az alap feltöltésére két forrást jelölt meg: a költségvetés tartalékát, illetve a nem kihasznált állami vagyonrészesedések eladásából befolyó tôkét. Ez utóbbi becsült mértéke több mint 200 millió euró.

A SYKALA mindenesetre deklarálta, hogy mindaddig harcolni fognak, amíg az óket ért igazságtalanság erkölcsi és anyagi terheit viselniük kell, és amíg ki nem derül, hogy ki volt a felelôs a hat éve kicsúcsosodott válságért. ${ }^{1}$

\section{AZ AKTUÁLIS GAZDASÁGI HELYZETKÉP}

Az elemzốk a ciprusi gazdaság kilátásait - bár számos kritikát is megfogalmaznak - alapvetôen pozitívan ítélik meg. A költségvetési adósságot ugyanis sikerült csökkenteni, és várhatóan ez a tendencia tovább folytatódik, a gondot azonban abban jelölik meg, hogy a csökkentést nem alapvetố strukturális átrendezôdés, hanem „túzoltó” jellegú lépések tették lehetővé.

Ciprus gazdaságának jellemzője, hogy a szolgáltatások (beleértve elsôsorban az idegenforgalmat és a pénzügyi szolgáltatásokat) rendkívül magas, $80 \%$ körüli arányt képviselnek az ország GDP-jében. Ebból következôen a termeló ágazatok jelentôsége jóval kisebb, az ipar például csak 15\%-kal járul hozzá a nemzeti ter- 
mékhez. Az egyoldalú gazdasági struktúra oldása szempontjából fontosak azok a kormányzati lépések, amelyek az eddig alulfejlett szektorok - mint például az egészségügy, az oktatás, az energetika továbbfejlesztését kívánják szolgálni. Elsôdleges jelentôsége volt azonban a 2013. évi gazdasági válság egyik fố kiváltó okait képező, ún. rossz ( non performing) hitelek volumene csökkenésének. 2014 és 2018 között ezeknek a hiteleknek az állománya $60 \%$-kal mérséklôdött, a fennmaradó hitelállomány volumene azonban még mindig a GDP 50\%-át teszi ki, és ez veszélyesen magas arány.

Rolf Strauch, az Európai Stabilitási Mechanizmus (ESM) vezető közgazdásza ennek ellenére egyenesen az ESM „sikertörténeteként” emelte ki egy nyilatkozatában Ciprust, különösen méltatta a gazdasági növekedés ütemét. ${ }^{2}$ Hozzátette, hogy a rossz hitelek csökkenésével párhuzamosan erôsödtek a ciprusi bankok, lehetôvé téve, hogy a ciprusi gazdaság szempontjából fontos pénzügyi szolgáltatási iparág visszanyerje régi vonzerejét.

A ciprusi Költségvetési Tanács (Fiscal Council) kevésbé optimista. Vezetóje szerint figyelmeztetéseiket, amelyekben óvnak a kormányzati sikertörténetek túlbecsülésétôl, érdekes módon nemcsak kormányoldalon, de az ellenzéki pártok részérôl is figyelmen kívül hagyják. Hiszen egyetlen politikai erőnek sem tetszenek olyan követelések, amelyek szerint csökkenteni kell a költségvetési kiadásokat, vagy takarékosabban kell az állami vagyonnal bánni! A Költségvetési Tanács 2019. nyári jelentése ${ }^{3}$ kifejti, hogy a költségvetési kiadások magas volta ellenére a kormány keveset költ infrastruktúrára, K+F-re vagy a társadalmilag hátrányos helyzetben levôk támogatására. Az állami bérek folyamatosan nőnek (és ennek az ellenzéki vezetôk is haszonélvezôi), nincsenek szociális bérlakások, és a lakásbérleti díjak egyre kevesebb ciprusi számára elviselhetôk.

A Költségvetési Tanács felhívja a figyelmet az alapvetôen az idegenforgalomra épüló gazdaságpolitika veszélyeire is, hiszen a gyengülő orosz rubel, angol font és török líra következtében elôreláthatóan csökken a beérkezô turisták száma. $\mathrm{Az}$ adóbevételeket például a török líra gyengülése is apasztja, mivel egyre több ciprusi görög jár át az északi országrészre bevásárolni az ottani jóval olcsóbb benzin-, élelmiszer- vagy gyógyszerárak miatt.

A ciprusi versenyképesség jellemzôi is alátámasztják az aggodalmakat. A kormány 2018 júniusában hozta létre a Gazdasági és Versenyképességi Tanácsot, amely most tette közzé elsô, Ciprus versenyképességét elemzôjelentését (Cyprus Economy and Competitiveness Council, 2019). Röviden összefoglalva a jelentés mondanivalóját, egyértelmúen kijelenthetô: a ciprusi versenyképesség elmarad az EU átlagától és kiválasztott 12 benchmark ország ilyen mutatóinak többségétól is. Az elemzés szerint a mintegy 150 mutató alapján az alacsony versenyképesség hátterében elsôsorban a gyenge üzleti szektor, az alacsony vállalkozói dinamizmus, az üzleti innovációk és a digitalizáció hiánya, az alternatív finanszírozási lehetôségekhez való nehéz hozzáférés, valamint az átlagosnál egyébként jobban képzett munkaerôn belül egyes szakmák teljes hiánya áll.

A ciprusi üzleti környezetet értékelve, a jelentés szerint vegyes a kép. A vállalkozásalapítás alacsony költségei, a relatív alacsony munkaerôköltségek (amely mögött a külföldi vendégmunkások magas 


\section{Tudományos múhely}

aránya áll), valamint az EU átlagához képest alacsonyabb üzleti ingatlanbérleti díjak vannak az egyik serpenyóben, ugyanakkor a magas energiaárak, különösen az elektromos energiáé, az internettel való ellátottság hiányosságai és az innovatív ágazatokhoz szükséges technikai szakképzettség hiánya orvoslást igényelnek.

Miból élünk most? - teszik fel sokan Cipruson a kérdést. A válasz: ingatlanértékesítésból és adóügyi kedvezményekkel idecsábított külföldi befektetôk pénzének kezeléséból; eladjuk a tengerpartunkat és a napfényt - hangzik a vád -, és mi lesz, ha elfogy az eladható tengerparti ingatlanvagyon? A feltett kérdésre adott kormányzati válaszban ismételten felmerül a ciprusi energiavagyon reménybeli értékesítése, illetôleg a sziget kettéosztottságának megszúnéséból származó gazdasági elônyök majdani kihasználása.

\section{Ciprus mint ENERgiahatalom?}

2011-ben fedezték fel, hogy a Ciprust környezô tengerek alatt számottevô gázvagyon rejlik. Az offshore készletek feltárásától sokan egy új ciprusi aranykor kezdetét remélték. Mindenesetre a sziget déli részén fekvô, ún. kizárólagos gazdasági övezetben (Exclusive Economic Zone of Cyprus) talált földgázmennyiség - legalábbis ciprusi mércével mérve - jelentôs gazdasági haszonnal kecsegtetett. Az elsôként feltárt gázmezô becsült volumene a szigetország belsố fogyasztási igényeit 100-150 évig fedezné, és még exportra is jutna belôle. Mindennek azonban számos feltétele van, és az eddigi tapasztalatok szerint gyors eredményre nem lehet számítani.

Már 2011-ben megjelentek a gázvagyon feltárását és kitermelését biztosító koncessziók megkötésére vonatkozó elsố tenderek, és mindössze fél év alatt megkötötték az elsố szerzốdést az amerikai Noble Energyvel, de ez csak a kutatófúrások elvégzésére vonatkozott.

Természetesen a hazai hasznosítás, illetve az exportlehetôségek kihasználása jelentôs beruházásokat igényel, amelyeket azonban Ciprus egyedül nem tud és nem is akar megvalósítani. Ezért fontos, hogy a földgázvagyon feltárásával kapcsolatban a térség országaival, például az ugyancsak jelentôs offshore készletekkel rendelkezô Izraellel és Libanonnal intenzívebbé váltak a politikai és gazdasági kapcsolatok. $^{4}$

A ciprusi energetikai miniszter, Jorgosz Lakkotrypisz legutóbbi sajtótájékoztatóján ${ }^{5}$ elmondta, hogy az elsôként kutatott mezô kitermelésérôl szóló szerzôdés aláírás elôtt áll a koncesszió tulajdonosaival (Noble Energy, Shell, Delek). A következô 24 hónapban Ciprus további nyolc tenger alatti fúrás beindítását tervezi, amelyek közül hat a feltárást, kettô viszont már a kitermelést célozná. A koncessziós tárgyalások azzal a közös vállalkozással folynak, amelyek tulajdonosai a francia Total és az olasz ENI. Tárgyalások folynak arról a tenger alatti vezetékrôl is, amely az egyiptomi Idkuban levô LNG-terminálhoz (liquefied natural gas) szállítaná a gázt, ahonnan kerülhetne tovább a világpiacra. Ciprus nem mondott le egy saját LNG-terminál létesítésérôl sem, de ehhez - mint a miniszter kifejtette - a jelenleg tervezettnél több gáz kellene, különben nem gazdaságos a múködtetése.

Természetesen Ciprus kettéosztottsága és az ezzel kapcsolatos politikai feszültségek jelen vannak a gázvagyon kérdését illetôen is. Törökország kétségbe vonja Ciprus jogát az egyedüli kitermeléshez, és 


\section{Tudományos múhely}

saját kutatófúrásokat kezdett a Ciprus környéki vizeken, amit viszont a görög oldal tekint illegálisnak. Ezzel kapcsolatban a legutóbbi konfliktus akkor alakult ki, amikor 2019 májusában Törökország a Fatih elnevezésú kutatóhajót a ciprusi Kizárólagos Gazdasági Zónába küldte, alig 60 kilométerre Páfosztól. A ciprusi kormány válaszul elfogatási parancsot adott ki a hajó személyzetére, beleértve a hajón tartózkodó angol és amerikai szakembereket is. Bár a lépés inkább csak szimbolikus jelentôségú, Ankara felháborodottan reagált. Recep Tayyip Erdogan török elnök szerint Törökországnak mint garantôr államnak nemcsak joga, hanem kötelessége is, hogy a földgáz feltárása kapcsán is megvédje a ciprusi törökök érdekeit, és kijelentette, hogy hadihajókat fognak rendelni a kutatást végzố hajók védelmére. A fúrásokat pedig ez év július elején kívánják megkezdeni (Ioannidou, 2019).

A kereskedelmi háborúk, a Brexit, néhány jelentôs valuta (például az orosz rubel vagy a török líra) erôs volatilitása a kis és nyitott gazdaságok növekedési kilátásait az átlagosnál is erôteljesebben befolyásolhatja. Hatványozottan igaz ez a kis mediterrán országra, Ciprusra. Az angolszász múlt (Ciprus sokáig angol gyarmat volt), a jelenlegi kapcsolatok miatt (több ezer brit állampolgár él állandó vagy idôszakos jelleggel a szigeten, minden ambiciózus ciprusi fiatal az Egyesült Királyság valamelyik egyetemén tanul, és nem utolsósorban brit katonai támaszpontok múködnek a szigeten), a Brexit kapcsán az átlagosnál is több kérdés merül fel a két ország jövőbeli viszonyát illetően.

Kérdőjelek vetődnek fel a szigeten lévó brit katonai támaszpontok jövőjével kapcsolatban is, amelyek a sziget területének mintegy 5\%-át foglalják el. A függetlensé- gi megállapodás szerint a volt gyarmattartó Anglia ezeken a területeken szuverén jogokat gyakorol. Tény azonban, hogy a hágai Nemzetközi Bíróság februárban hozott, nem kötelezô érvényú állásfoglalására alapozva az ENSZ Közgyúlés egy másik, hasonló módon birtokolt katonai támaszpont ügyében felszólította Angliát, hogy hat hónapon belül szüntesse meg a törvénytelen, gyarmatosító helyzetet, és adja vissza a támaszpont területét jogos tulajdonosának, Mauritiusnak. (Az ENSZ állásfoglalását 116 ország támogatta, és csak öt ország - köztük Magyarország - ellenezte.) A fenti események után Ciprus azonnal bejelentette, hogy kérni fogja a ciprusi brit katonai támaszpontok helyzetének felülvizsgálatát.

$\mathrm{Az}$ újraegyesítési tárgyalások sorozatos kudarcának elemzése egy külön írás tárgya lehetne. Fontos fejlemény, hogy az Észak-ciprusi Török Köztársaság 2019 májusában kinevezett új „miniszterelnöke”, Ersin Tatar mindenesetre sietett kijelenteni, hogy az eddigi tárgyalási alapot szolgáló megoldás, a föderális államszövetség kialakítása számára nem elfogadható. Tatar, aki köztudottan jobban kötôdik Törökországhoz, mint elôdei, azt nyilatkozta, hogy a föderalizmus felett már eljárt az idő, és a szigeten csak két független állam képzelhetô el, mindkettô EU-tagsággal. Egyidejúleg még szorosabbá kívánja fúzni a gazdasági és politikai kapcsolatokat Törökországgal (Andreou, 2019). Ez az álláspont a további újraegyesítési tárgyalások végét is jelentheti. $\mathrm{Az}$ utolsó alkalommal, Crans-Montanában 2017-ben tartott kétoldalú tárgyalások kudarca után egyébként már senki nem volt optimista ezen a téren.

E sorok írójának meggyốzôdése szerint nem Cipruson születik majd döntés 


\section{Tudományos múhely}

a kettészakított ország jövôjérôl. Valódi nagyhatalmi akarat és nyomás esetén ugyanis az újraegyesítést már régen el lehetett volna érni. Az USA számára Ankara fontos, és a törökországi demokráciával kapcsolatos kritikák nem elég súlyosak ahhoz, hogy a jelenleg kialakult egyensúlyt megbontsák. Az Európai Unióban pedig az Észak-Ciprussal kapcsolatos bírálatok alkalmasak arra, hogy Törökországnak az EU-tagsággal kapcsolatos igényeit - ha egyáltalán még vannak ilyenek - sakkban tartsák. Az Egyesült Királyság pedig - mint ismert - a Brexittel van elfoglalva, és szintén nem igazán érdekelt a jelenlegi helyzet megbolygatásában.

\section{JEGYZETEK}

1 A ciprusi gazdasági válságról részletesebben lásd Botos, 2013.

2 Cyprus Mail, May 27, 2019.

3 Cyprus Mail, June 19, 2019.
4 A ciprusi földgázvagyon hasznosításával kapcsolatos külpolitikai vonatkozásokról részletesen beszámol Kacziba Péter cikke: Kacziba, 2013.

5 Cyprus Mail, May 21, 2019

\section{FELHASZNÁLT IRODALOM}

Andreou, Evie (2019): Clash in North Over Direction of Cyprus Problem. Cyprus Mail, May 23, https://cyprus-mail.com/2019/05/23/clashin-north-over-direction-of-cyprus-problem/.

Botos Balázs (2012): Ciprus: Európa és Törökország között. Polgári Szemle, 8. évf., 1-2.

Botos Balázs (2013): A ciprusi gazdasági összeomlás természetrajza. Külügyi Szemle, 12. évf., 4. sz., 133-148.

Cyprus Economy and Competitiveness Council (2019): 2019 Cyprus Competitiveness Report. Nicosia.

Ioannidou, Lizzy (2019): Erdogan: We Have the Ships, We Will Drill. Cyprus Mail, June 13, https://cyprus-mail.com/2019/06/13/erdogan-we-have-the-ships-we-will-drill/.

Kacziba Péter (2013): A ciprusi földgázkincs feltárásának bel- és külpolitikai sajátosságai. Külügyi Szemle, 12. évf., 4. sz., 149-171. 